\title{
Når skolens børn evaluerer sig selv
}

\author{
Lise Aagaard Kaas, lektor, Københavns Professionshøjskole, \\ liak@kp.dk \\ Mathias Sune Berg, lektor ph.d., Københavns Professionshøjskole, \\ masb@kp.dk \\ Sine Penthin Grumløse, lektor ph.d., Københavns Professionshøjskole, \\ sipg@kp.dk
}

\begin{abstract}
Resume
I overensstemmelse med ideen om livslang læring forventes skolebørn i stigende grad at vurdere, hvad de har lært. Karakteristisk for disse selvevalueringspraksisser er, at de ikke kun knytter sig til børnenes faglige kompetencer. De går ofte også tæt på børnenes mere personlige forhold. Derudover er evaluering en del af den skolepolitiske dagsorden, hvor læreren er forpligtet på at dokumentere elevernes læring.

I denne artikel går vi tæet på undervisningen og præsenterer eksempler på evalueringspraksisser, der skaber vidt forskellige deltagelsesmuligheder for børnene. Der er fokus på aktiviteter, hvor børnene skal vurdere, hvad de har lært, gennem brug af evalueringsværktøjer som portfolio og læringsplatforme. Vi diskuterer den udspændthed, som læreren befinder sig i mellem på den ene side at efterleve politiske krav om evaluering og på den anden side at praktisere evaluering, der kan udvikle undervisningen og styrke børnenes trivsel og læring samtidig med hensynet til børnenes behov og forudsætninger.
\end{abstract}

Nøgleord: selvevaluering, deltagelse, social sortering, differentiering, portfolio, læringsplatform.

\begin{abstract}
According to the idea of lifelong learning, schoolchildren are increasingly expected to assess what they have learned. Characteristic of these self-assessment practices is that they do not only relate to the children's professional competencies. They also address children's personal issues. In addition, assessment has become part of the school policy agenda, where the teacher is obliged to document students' learning.

In this article, we focus on teaching and examples of assessment practices that create vastly different participation opportunities for different children. There is a focus on activities where the children must assess what they have learned through portfolios and learning platforms. We discuss the cross bind that teachers find themselves in between complying with political demands for assessment and, practicing assessment that can develop teaching and strengthen children's well-being and learning while taking into account children's needs and prerequisites.
\end{abstract}

Keywords: self-assessment, participation, social classification, differentiation, portfolio, learning platform 


\section{Indledning}

I de seneste 30 år har evaluering været en del af lærerens professionelle værktøjskasse ud fra et rationale om, at evalueringer kan danne grundlag for at udvikle og forbedre undervisningen. Men evalueringspraksisserne har i samme periode udviklet sig. Herunder har fokus flyttet sig, så det i dag er mindre rettet mod undervisningens kvalitet og mere rettet mod elevernes udbytte af undervisningen (Andersen, 2011). Et af tidens aktuelle værktøjer til at styrke elevernes udbytte af undervisningen er brugen af selvevaluering, hvor eleverne gennem refleksioner over egne læreprocesser og præstationer forventes at blive ansvarliggjort og motiveret til at lære bedre og mere (Andersen, 2011; Krejsler, 2019). Det betyder, at en del af skolens evalueringsprocesser i dag er kommet ganske tæt på det enkelte barn (Kousholt, 2009; Kousholt et al., 2019).

Med afsæt i forskningsprojektet Skolens Børn diskuterer vi i denne artikel, hvordan skolens selvevalueringspraksisser opleves af børnene og får betydning for deres deltagelsesmuligheder i undervisningen og skolens sociale fællesskaber. Vi har valgt at kigge med børnene på nogle af klasserummets efterhånden almindelige processer og sætter fokus på, hvad der egentligt foregår, når børn skal tage stilling til 'det, de har lært'. Det gør vi ved at zoome ind på nogle konkrete aktiviteter, hvor børn skal evaluere deres udbytte af undervisningen. Vi diskuterer undervejs, hvordan brugen af forskellige selvevalueringsværktøjer ser ud til at stille forskellige krav til børnene, og hvilke lærerfaglige overvejelser brugen af selvevalueringsredskaberne inviterer til. Afslutningsvis diskuterer vi, hvordan brugen af selvevaluering får en sorterende funktion, hvor det ikke bare er de børn, der har vanskeligheder ved at leve op til skolens krav om faglig udvikling i et 'passende' tempo, der kommer i problemer, men også fagligt stærke børn, der af forskellige grunde er usikre eller befinder sig i sårbare positioner.

\section{Skolens børn}

\section{- når børn evaluerer, hvad de kan, og hvem de er}

Forskningsprojektet Skolens Børn (Grumløse et al., 2020) er et etnografisk observationsstudie (Gulløv \& Højlund, 2015; Hedegaard-Sørensen \& Grumløse, 2016; Hastrup et al., 2017) med interesse for børnenes oplevelser af hverdagen i skolen og selvevaluering som social praksis (Kousholt, 2016). I 
projektet søger vi således svar på, hvad selvevaluering er i folkeskolen anno 2018, og hvordan de aktuelle praksisser opleves af børnene.

Projektet skriver sig ind i den forskning, der undersøger de konstitutive virkninger af aktuelle optimeringstiltag i skolen, herunder diverse evalueringspraksisser (Kousholt, 2009; Bartholdsson, 2009; Krejsler, 2013; 2019; Hamre, 2012). I dette perspektiv betragtes selvevalueringsværktøjer som styringsteknologier, der er udviklet for at dokumentere og måle elevernes præstationer med mulighed for at sammenligne dem. Ikke overraskende retter en del af denne forskning kritik mod den skolepolitiske udvikling og dennes indflydelse på skolens undervisningspraksis. I en dansk skole- og uddannelseskontekst handler dette blandt andet om, at der er sket et skifte fra en primært dannelsesorienteret diskurs til en mere læringsmålsstyret diskurs:

\section{"Uddannelsestænkningen (...) illustreres med udviklingen mod en 'læringsmålstyringstænkning.' Betegnelsen antyder den væsentligste udvikling: udviklingen fra at betragte uddannelsespolitik som en pæda- gogisk, kulturel livsform hen imod at betragte uddannelsespolitikken som en styringsform med fokus på opstilling af målbare mål og stan- darder eller kompetencemål med dermed sammenhængende nationale og internationale målinger og sammenligninger af elevernes resultater. Uddannelsespolitikken skifter fokus fra uddannelsens formål til uddan- nelsesmål, hoor målene bliver nationale eller internationale målinger (OECD)(Biesta, 2011)" (Moos (red.), 2019, s. 41)}

Når uddannelsespolitikken skifter fra at være en kulturel livsform henimod en styringsform, influerer det naturligt på hverdagen i skolen (Skovmand, 2019). Lærerne forpligtes som en konsekvens heraf på, at eleverne skal tilegne sig en specifik viden og udvikle specifikke kompetencer, der kan dokumenteres gennem brug af varierede evalueringsformer. I forlængelse heraf retter den kritiske evalueringsforskning blikket mod, hvordan evalueringspraksisser forsøges anvendt som løftestang for udøvelse af magt og kontrol (Asp-Onsjö, 2011; Bartholdsson, 2009), ligesom de involverer bestemte forståelser af dygtighed og skaber ændrede betingelser for børns deltagelse i skolen (Kousholt, 2009; Krejsler, 2004; 2019; Hamre, 2012; Tanner \& Prieto, 2014; Kousholt \& Hamre, 2016). I tilknytning til denne forskning retter vi blikket mod, hvordan brugen af selvevaluering får betydning for skolens børn, herunder hvilke krav der knytter sig til at kunne evaluere sig selv, og 
hvordan børn møder og honorerer disse på forskellige måder og med forskellige konsekvenser som følge.

Projektets empiriske materiale består først og fremmest af klasserumsobservationer (Hedegaard-Sørensen, 2015) og uformelle samtaler med børn og lærere (Hastrup et al., 2017). Gennem hele skoledage i en periode på seks uger fulgte vi i 2017-2018 seks klasser på 2., 3. og 4. klassetrin.

Analyserne er informeret af dels den kritiske psykologis fokus på børns deltagelsesbetingelser og handlemuligheder i undervisningen (fx Stanek, 2011; Højholt, 2014), dels på klasserummets sociale processer (fx Gilliam, 2012; Kousholt, 2016), hvormed blikket rettes mod de sammenhænge og betingelser, der etableres for børns skoleliv $i$ hverdagen. I feltarbejdet har vi bestræbt os på at kigge med børnene og kigge bredt på deres hverdagsliv. Det betyder helt konkret, at vi har søgt at få indblik i, hvordan det opleves, når man som en naturlig del af sit skoleliv skal vurdere 'sig selv'. Det er dermed nogle særlige aktiviteter og situationer, som vi med et intenderet børneperspektiv har søgt indblik i, men vi forstår disse som del af en større og ikke mindst kompleks praksis, hvor læreres undervisningspraksis og børns betingelser for at deltage som elever i skolens undervisning hænger uløseligt sammen (Berg, 2018; Knudsen, 2015; Højholt \& Kousholt, 2018; Hedegaard-Sørensen \& Grumløse, 2016; Mardahl-Hansen, 2019).

Igennem vores observationer har vi fået indblik i, hvordan der i løbet af skoledagen etableres en række implicitte og eksplicitte forventninger til børnene om at tage stilling til sig selv og det, de har lært. Dette fører til, at nogle deltagelsesformer blandt børnene anerkendes, og andre underkendes, og at nogle børn indgår problemfrit heri, mens andre strides med at deltage. En måde at betragte dette på er at betragte det som social sortering (Bourdieu \& Passeron, 2006; Palludan, 2017). Det er i den forbindelse væsentligt, at der er ganske stor forskel på, hvornår og hvordan børn vurderes og skal vurdere sig selv. Nogle børn møder en høj grad af summative faglige evalueringer i deres skoletid, mens andre børns skoledag er bygget op omkring en didaktik, hvor barnets egen stillingtagen til fx faglige mål er en del af de daglige aktiviteter. Ligeledes møder nogle børn oftere kravet om at tage stilling til eget udbytte af undervisningen end andre (Grumløse et al., 2020). Det betyder også, at vi i vores observationer møder en række ret forskellige aktiviteter, der i bund og grund blot har det til fælles, at det er aktiviteter i undervisningen, hvor børnene forventes at evaluere sig selv. Dette sker i spændet mellem deres faglige udbytte af undervisningen, deres sociale adfærd og aspekter af deres personlighed. 
Med udgangspunkt i to empiriske nedslag vil vi i det følgende se nærmere på, hvordan børns betingelser for deltagelse etableres og udfordres i aktiviteter, hvor børn forventes at vurdere og reflektere over, hvad de har lært. Det første eksempel er en aktivitet, hvor børnene skal tage stilling til, hvad de har lært, gennem en evaluering i læringsplatformen Meebook. Det andet eksempel er en aktivitet, hvor børnene skal evaluere deres udbytte af undervisningen gennem brug af portfolio. De valgte situationer er særlige i den forstand, at de ikke nødvendigvis finder sted på mange skoler præcis i denne form. Men de er samtidig eksemplariske i den forstand, at mange børn på daglig basis forventes at evaluere og reflektere over, hvad de har lært, og forskellige selvevalueringskoncepter ofte er del af den didaktiske praksis. Derudover er læringsplatforme såvel som portfoliobaseret undervisning udbredte i folkeskolen. Det er med andre ord et grundvilkår i meget undervisning, at børn selv skal vurdere, hvad de har lært. Dette fokus på det enkelte barns udbytte af undervisningen understøttes af den aktuelle skolepolitik og intentionen om at højne børns udbytte af undervisningen (Pedersen, 2011; Illeris, 2014; Kousholt \& Hamre, 2016; Kousholt et al., 2019).

\section{To nøglebegreber: differentiering og evaluering}

Med folkeskolereformen i 1993 indførtes undervisningsdifferentiering som et bærende princip for undervisningen (Folkeskolereformen, 1993). Med en intention om at løfte alle børns faglige kundskabsniveau inden for en ramme af fællesskabet var det intentionen, at undervisningen skulle tilrettelægges med udgangspunkt i den enkelte elevs behov og forudsætninger (Hedegaard-Sørensen \& Grumløse, 2016). Udgangspunktet for lærernes tilrettelæggelse af undervisningen forventedes at være et indgående kendskab til hver enkelt elevs faglige og sociale forudsætninger, og i relation til det mente man, at evaluerende metoder ville understøtte børnenes fremtidige progression. Kongstanken var, at eleven skulle have viden om egen faglige udvikling og på den baggrund kunne justere sin deltagelse i undervisningen (Folkeskoleloven 1993, § 13. Stk. 2). Derved skulle børnene tage et større medansvar for deres læringsforløb. Vi kender det som 'ansvar for egen læring' (Bjørgen, 2008).

I første omgang var det altså læreren, der forventedes at evaluere barnets udbytte af undervisningen med henblik på at justere undervisningen og barnets deltagelse for at sikre, at barnet fik et større udbytte af undervisningen. I dag er en del af dette vurderende arbejde blevet barnets (Kousholt, 2009; 


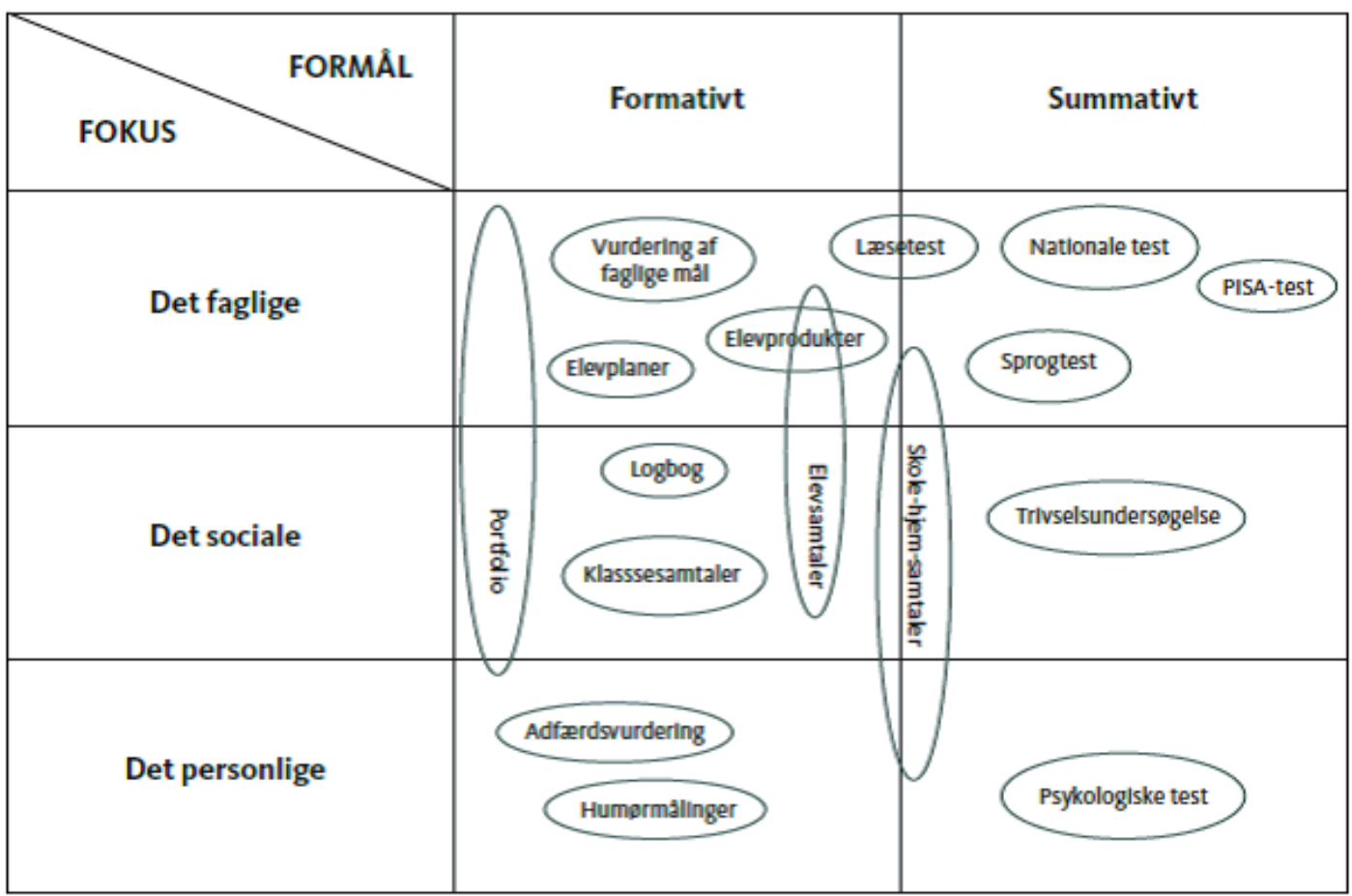

Figur 1. Evalueringslandskabet - eksempler på formative og summative evalueringsformer som børn møder $i$ skolen $i$ dag.

Kousholt et al., 2019). Med et (politisk) ønske om at styrke børnenes udbytte af skolen er selvevaluering trådt frem som et mere selvstændigt begreb. Til forskel fra evaluering er selvevaluering kendetegnet ved, at evalueringen foretages af det lærende individ og dermed eleven selv (Andersen, 2011). Dette er blandt andet understøttet af brugen af digitale læringsplatforme, hvor børnenes 'evaluering af sig selv' er en integreret del af undervisningen og som sådan kan betragtes som en 'naturlig' del af børns engagement for at blive dygtige i skolen (Pasgaard, 2017; Thomsen, 2017). Derudover er der et stigende fokus på sammenhængen mellem trivsel og læring og en grundlæggende forståelse af, at børn, der har det godt, kan lære mere. På den konto er også mere terapilignende forløb blevet del af skolens hverdag og praktiseres parallelt med diverse evalueringer af faglige mål (Frykman, 2005; Hamre, 2012; Dressler \& Obel, 2017; Grumløse et al., 2020).

En konsekvens af skolens intention om både at styrke børnenes trivsel og faglige præstationer er, at der i dag anvendes et væld af forskelligartede evalueringsformer, der kan karakteriseres som henholdsvis summative (til- 
bageskuende) og formative (fremadrettede) (Ecclestone, 2003). Således beror nogle formater på ideen om, at man kan "høste" viden om børnene og det, de kan, mens andre antager, at viden om læring er noget, det enkelte barn har og skal udnytte i arbejdet med at lære mere. Modellen illustrerer, hvordan henholdsvis summative og formative evalueringsformer knytter an til evalueringer af børnenes faglige, sociale og personlige kompetencer. Dog skal det bemærkes, at hvorvidt evalueringsmetoderne kan kategoriseres som værende formative eller summative afhænger af, hvordan de anvendes i praksis. Det betyder, at børn i dag møder et miskmask af evalueringsformer, hvor både form og indhold veksler. Nogle dage er der nationale test på programmet, og andre dage forventes barnet selv at vurdere og reflektere over egne læreprocesser, sociale relationer eller personlige forhold og i øvrigt at profitere af denne viden (Grumløse et al., 2020). I det følgende skal vi se nærmere på nogle af de didaktiske værktøjer, der anvendes i undervisningen, når børnene skal vurdere deres læring og deltagelse i undervisningen. Vi tager udgangspunkt i konkrete situationer fra praksis, hvor børn forventes at evaluere deres faglige udbytte af undervisningen gennem brug af læringsplatforme og portfolio. Begge redskaber betragter vi som styringsteknologier; der er en grund til, at de er taget i anvendelse: De forventes at styrke børnenes udbytte af undervisningen ved at internalisere bestemte måder at agere på - og får således indflydelse på, hvordan børnene tager del i undervisningen (Krejsler, 2014). Der sker dog også andet, når børnenes deltagelsesmuligheder, oplevelser af mestring og ansvar for egen læring påvirkes i negativ retning.

\section{Deltagelsesmuligheder og selvevalueringspraksis}

Med udgangspunkt i Charlotte Højholts forståelse af deltagelse som en individuel handling med 'nogle rettet mod noget' (Højholdt \& Witt, 1996) retter vi i det følgende blikket mod, hvordan selvevalueringsaktiviteter indgår i den didaktiske tilrettelæggelse af undervisningen, og hvordan læreren forventer, at børnene deltager. Her bliver det tydeligt, at bestemte forståelser af, hvad skoledygtighed er, er på spil på måder, der ikke altid er ekspliciterede og tydelige for børnene (og måske heller ikke for læreren). Når det er væsentligt, hænger det samme med, at børnene ser ud til at have vidt forskellige deltagelsesmuligheder i selvevalueringsaktiviteterne. Nogle børn har tilmed så begrænsede muligheder for at deltage, at det fører til oplevelser af utilstrækkelighed og eksklusion (Grumløse et al., 2020). Som 
også Kristine Kousholt viser i sin forskning, bliver det netop i evalueringerne tydeligt, at nogle børn først og fremmest erfarer, at de ikke præsterer tilstrækkeligt:

\section{"Skolens evalueringspraksis skaber forskellige forståelser af dygtighed og legitimerer særlige former for dygtighed, som skolens evaluering igen skal evaluere. Skolen er struktureret ud fra en antagelse om nødvendig fremadskridende udvikling, hoilket kan skabe dygtighedsunderskud og mangelforståelser hos nogle børn (Højholt, 2001; Kousholt, 2006)". (Citeret fra Kousholt, 2016, s. 54)}

Tilsvarende bliver det tydeligt, at selvevalueringsaktiviteterne influerer på lærerens didaktiske tilrettelæggelse af undervisningen. I nogle sammenhænge udvides børnenes deltagelsesmuligheder, fordi de arbejder i læringsfællesskaber, og i andre sammenhænge begrænses børnenes deltagelsesmuligheder, fordi selvevalueringen foregår som en individuel aktivitet uden mulighed for støtte og inspiration fra klassekammeraterne. Derudover bidrager selvevalueringsaktiviteterne til forskydninger i fordelingen af ansvar mellem børn og lærere, idet børnenes udbytte af undervisningen per definition bliver genstand for forhandling. "Hvad kunne barnet have gjort for at have fået mere ud af undervisningen?", bliver således et relevant spørgsmål i disse sammenhænge. Det omvendte spørgsmål: "Hvad kunne have været anderledes i undervisningen?", møder vi til gengæld ikke. Svaret (og ansvaret) ligger hos det enkelte barn.

\section{Læringsplatforme som selvevalueringsinstrument}

Læringsplatforme er, til trods for at de i dag ikke længere er lovpligtige, grundlaget for meget undervisning i den danske folkeskole. I flere af de klasser, vi har fulgt, evaluerer børnene løbende deres udbytte af undervisningen via læringsplatforme som MinUddannelse og Meebook. I det følgende kigger vi på, hvad der udspiller sig i disse sammenhænge. Hvordan er undervisningen organiseret, og hvilken funktion har selvevalueringsaktiviteter heri? Hvilke muligheder har børnene for at deltage? I forlængelse heraf diskuterer vi, hvordan læringsplatformene ser ud til at udfordre lærernes faglighed og deres pædagogiske arbejde med at etablere god undervisning for alle børn.

Vi starter i 3. klasse, hvor klassens natur- og teknologilærer arbejder struktureret og systematisk med evaluering af elevernes læringsudbytte i et 
undervisningsforløb om kroppen. Klassen skal bruge Meebook til formålet, og børnene har fundet deres iPads frem:

Peter, klassens lærer, introducerer opgaven $i$ en opmuntrende tone: "Der er tre små mål, læs dem.... Jeg ved, I er virkelig gode til det. Der er tre små mål. I gør det bare så godt, som det er muligt. Det er ikke en stavekonkurrence, men man skal skrive det. Da jeg gik i tredje klasse, kunne jeg heller ikke skrive helt perfekt. I må love mig ikke at gå i spåner!"

Der er lidt uro, mens børnene langsomt kommer på plads med deres iPads og logger ind. Der er stadig et par stykker, der mangler en iPad. Peter forlader klassen for at hente et par stykker mere.

Samir lister forbi med et smil og en finger på laben, som ville han sige: "Du må ikke sige noget". Så tjekker han plakaten med påtegnede muskler og vender derpå tilbage til sin plads. Benjamin løber lystigt frem og tilbage.

Børnene er i gang. Der er let snak rundt i lokalet. En pædagog går rundt mellem bordene og hjælper børnene. Både Peter og pædagogen taler $i$ et let forhøjet toneleje: "Jaa, det er rigtigt, I er seje". De opmuntrende kommentarer suppleres af små støttende berøringer på børnenes skuldre. Abas går rundt $i$ små cirkler lige bag ved Peter og spørger så om hjælp, mens han sukker højlydt. Peter fører ham hen foran tavlen, hvor det laminerede papir med klassens arbejdsregler hænger. Han peger på den regel, hvor der står, at børnene skal være stille. Derpå følger han Abas tilbage til sin plads.

De fleste børn er fxrdige, men der sidder stadig seks elever tilbage på deres pladser. Resten fylder på forskellig vis rummet op med dans, grin, råb og snak. Peter er ude af klassen. Da han kommer tilbage, klapper han rytmen, der indikerer, at børnene skal lytte. Lidt efter husker han dem på, at de skal være stille. Benjamin danser, skriver et ord, måske fire, inden nye dansetrin skal afsted, denne gang fra stolen... Derefter vender han sig mod makkeren til venstre. Peter reagerer ved at følge Benjamin ud på gangen.

Alfred er en af de sidste tilbage. Han veksler mellem dybe suk, fordybelse og lange blikke mod døren, der jæonligt åbnes og lukkes af de mange børn, der er fardige. Til sidst lægger han hovedet $i$ hænderne. De store øjne er let blanke. Da Peter blidt aer ham over håret, svarer han: "Jeg må vxre den dummeste og langsomste i klassen".

Som det fremgår af observationen, deltager børnene i evalueringsaktiviteten på vidt forskellige måder. Nogle børn kommer let og ubesværet igennem, mens andre anstrenger sig for at opfylde kravene, men efterlades (trods deres anstrengelser) med en følelse af utilstrækkelighed. Eksemplet minder os om, at evalueringsaktiviteter er konstitutive, dvs. at de ikke blot bidrager med viden om, hvad børnene har lært. De griber også ind i sko- 
lens praksis og forandrer den (Dahler-Larsen, 2005). I relation til ovenstående betyder det fx, at evalueringsaktiviteten har indflydelse på børnenes forståelse af dem selv som mere eller mindre skoledygtige børn. Nogle børn finder (som Samir) smarte måder at komme omkring lærerens evalueringskrav, som ikke udstiller deres manglende faglige kundskaber, og på måder, hvor de undgår 'at slå sig' på aktiviteten. Mens andre børn (som Alfred) kommer til at befinde sig i en situation af magtesløshed og oplever sig selv som utilstrækkelige. Paradoksalt nok er det ikke nødvendigvis de børn, der har vanskeligheder med at honorere skolens faglige krav, der oplever at have et 'dygtighedsunderskud'. Alfred er et barn, der på mange måder har let ved at leve op til skolens faglige krav. Men i evalueringsaktiviteten efterlades han med en forståelse af sig selv på den måde, som evalueringsaktiviteten giver ham mulighed for at forstå sig; nemlig som en, der er langsom (og dum) og uden for det 'hurtigere' klassefællesskab. Børn som Samir kommer på mange måder lettere omkring skolens evalueringskrav - $\mathrm{i}$ hvert fald $\mathrm{i}$ den konkrete situation - men på længere sigt vil børn som Samir sandsynligvis også opleve, at de tilbagevendende evalueringer bliver personlige nederlag, hvor mangler og underskud bliver tydelige, også for børnene selv.

Eksemplet illustrer således, at skoledygtighed ingenlunde 'bare' handler om at indfri de faglige mål i skolen. Skoledygtighed involverer også evalueringsdygtighed (Kousholt, 2009). Et skoledygtigt barn bliver i den forstand også et barn, der kan honorere skolens krav om at evaluere egne faglige præstationer inden for de rammer og aktiviteter, som aktuelt tilbydes i undervisningen.

\section{Lærerfaglighed og evalueringsdidaktik}

Vender vi blikket mod lærerens undervisning, er der tale om en lærer, der systematisk og jævnligt lader børnene evaluere deres udbytte af undervisningen i relation til de beskrevne læringsmål. Læreren kan med andre ord beskrives som en (evaluerings)dygtig skolelærer, der med stringens og vedholdenhed imødekommer krav og forventninger og løser undervisningsopgaven, som den er ham pålagt (når læringsplatformen er afsættet for hans undervisning). Derudover er han bevidst om, at selvevalueringsaktiviteterne ikke er en rar oplevelse for alle børn, hvilket han søger at kompensere for ved at støtte og opmuntre børnene med peptalks og omsorgsfulde berøringer. Han søger aktivt at skabe nærvær og omsorg, der når alle børn lige netop der, hvor de er følelsesmæssigt. Vi ser samtidig en undervisning, 
hvor den aktuelle evalueringspraksis udfordrer kravet om differentiering. Målene er ikke differentierede og afspejler ikke en individuelt tilrettelagt undervisning med fokus på det enkelte barns faglige læring og udvikling. Der er heller ikke forskel på, hvordan man kan deltage i evalueringen. Man kan svare - eller erfare, at man ikke har svar - på spørgsmålene, som stilles. Det differentierede er i denne sammenhæng ikke undervisningen, men børnenes betingelser for at deltage. De præfabrikerede læringsmål giver ikke det enkelte barn mulighed for at have medindflydelse på, hvad der skal læres i det enkelte forløb, og indebærer, at børnene i denne sammenhæng ikke møder passende udfordringer i undervisningen (Laursen, 2017). Nogle børn oplever, at kravene er for store, og andre oplever, at de er for små. Det kommer således til at handle mindre om børnenes læreprocesser og mestringsoplevelser og mere om at kunne gengive et lærerdefineret indhold (Skaalvik \& Skaalvik, 2015). I praksis betyder det, at børnene ikke evaluerer, hvad de har lært, men hvad de er blevet undervist i. Med Olga Dysthes begreber er der tale om evaluering af læring - og ikke evaluering for læring (Dysthe, 2009). Denne tendens bliver særligt tydeligt i en anden klasse, hvor børnene skal evaluere læringsmål i læringsportalen MinUddannelse. Det drejer sig om 4. klasse, der en formiddag skal evaluere mål i musik, dansk, matematik og engelsk:

\section{Læreren, Agnete, understreger, at det er en individuel opgave. Man må ikke tale med hinanden. Agnete tilføjer, at børnene selv skal vurdere, hoad de kan i musik, for hun ved det ikke (klassen har en anden lærer $i$ musik). Flere børn småsnakker med hinanden om evalueringen. I dansk skal eleverne evaluere flere forskellige undervisningsforløb: eventyr, svensk/norsk, salmer. Agnete læser teksten op og siger: "I må gerne give jer selv en stjerne, hvis I kan det, I evaluerer". Isak har sat en stjerne længere nede i prøven, men bliver bedt om at gå tilbage. Agnete siger: "I må tage stilling til, om I skal have en stjerne eller ej. Har du forstået, at man skriver et eventyr på én måde og en opskrift på en anden måde, så kan man give sig selv en stjerne". En del børn har givet sig selv en stjerne på emner, som de endnu ikke er blevet undervist $i$. Det går ikke, og Agnete beder dem slette dem igen.}

Ovenstående observation er et eksempel på, hvordan selvevalueringer praktiseres som evaluering af læring, med den konsekvens, at de får en kontrollerende funktion i forhold til at tjekke, om børnene har lært det, der var 
lærerens hensigt. Intentionen er med andre ord ikke at få indsigt i børnenes læring og viden om, hvordan undervisningen fremadrettet kan kvalificeres, altså evaluering for læring (Dysthe, 2009). I stedet fungerer selvevalueringen som en slags læringsjournal, der føres af barnet. Det er bemærkelsesværdigt, at evalueringen finder sted løsrevet fra læringssituationen, hvilket ser ud til at skabe endnu dårligere betingelser for, at børnene kan forstå og tage stilling til de konkrete udsagn. Der evalueres tilmed læringsmål, som andre lærere har undervist i, hvilket skaber udfordringer i forhold til at hjælpe børnene med at afkode, hvad de 'burde have lært'. Dette med stor forvirring og usikkerhed blandt børnene til følge (Grumløse et al., 2020).

Praksiseksemplet vidner således om et fortsat behov for at undersøge, hvordan aktiviteter som disse harmonerer med den lærerfaglige dømmekraft, der netop burde inkludere en langt bredere viden om børnenes betingelser for deltagelse, mellemmenneskelige erfaringer og pædagogiske overvejelser (Engsig, 2019; Pedersen, 2017), end der levnes plads til i sådanne snævre aktiviteter. Praksiseksemplerne vidner ligeledes om, at lærerne forholder sig ret forskelligt til de lærerfaglige udfordringer, som udspiller sig i begge situationer. I det første eksempel møder vi en lærer, der søger at skærme børnene og hjælpe dem igennem aktiviteten og på den måde inddrager sin viden om børnene. I det andet eksempel møder vi en lærer, der udfører opgaven, som den er stillet. Det er ikke noget, der sættes spørgsmålstegn ved, og ser som sådan heller ikke ud til at forstyrre det lærerfaglige arbejde, der finder sted. Tilbage står spørgsmålet: Hvordan kan evalueringerne tilrettelægges, så de giver mening under hensyn til børnene og det læringssyn, som undervisningen er forankret i (Dysthe, 2009)? Et forsøg på at styrke denne sammenhæng finder vi i en af de klasser, der arbejder systematisk med portfolio i undervisningen. Portfolioen danner ligeledes udgangspunkt for de efterfølgende skole-hjem-samtaler.

\section{Portfolio som didaktisk redskab}

I arbejdet med portfolio ${ }^{1} \mathrm{i}$ undervisningen og som grundlag for skole-hjem-samarbejdet ser vi et forsøg på at styrke elevernes ejerskab af og

1 Portfolio eller portefølje er en dokumentmappe eller en samling af dokumenter, hvor eleven kan samle dokumentation for sit skolearbejde. Hensigten er, at barnet skal få overblik over egen læring. Portfolio rummer derfor også elevens refleksioner over egne læreprocesser på baggrund af tydelige og realiserbare mål og kriterier (Madsen, 2006). 
fællesskab omkring de selvevaluerende processer. Brugen af portfolio handler i udgangspunktet ikke om, at børnene skal vise, at de har lært det, der var lærerens intention, men om at vurdere, hvad der understøtter deres deltagelse i undervisningen. Skoledygtighed handler derudover om meget andet end faglige kundskaber og færdigheder, men udfolder sig inden for en mere bred forståelse af, hvad det vil sige at være et skoledygtigt barn. Først og fremmest skal børnene dog fremstå som samarbejds- og evalueringsdygtige. Herunder som børn, der har lyst til læring og udviser ansvar for at dygtiggøre sig. I det følgende skal vi se nærmere på, hvad der udspiller sig, når børnene skal reflektere over, hvordan de har arbejdet, og hvilke produkter de vil præsentere for lærere og forældre. I forlængelse heraf vender vi tilbage til, hvilken rolle læringsfællesskaber spiller for at skabe deltagelsesmuligheder og oplevelser af mestring for børnene.

I 3. klasse forbereder børnene en præsentation af deres portfolio, der skal danne afsæt for en kommende skole-hjem-samtale. Det forløber blandt andet sådan her:

Læreren, Aske, fortæller, at denne skole-hjem-samtale er børnenes samtale. Denne dag er sidste chance for, at bornene kan forberede samtalen. Det foregår på den måde, at eleverne skal øve deres præsentationer for hinanden $i$ smågrupper. Eva, Josefine og Frederikke er i gruppe sammen. De går til præsentationerne, som var det et skuespil. De starter med at fordele far- og mor-rollen. Eva starter. Hun siger: "Hej far og mor og Aske og Katinka. Jeg vil gerne præsentere min blærerøvs-portfolio". Hun starter med at vise de produkter, hun har udvalgt. Hun gør meget ud af at sige, hoad der var let eller svart. Selve arbejdsprocessen og refleksioner over, hvad hun lærte, fär mindre opmærksomhed. Et af kriterierne i portfolioen handler om noget, som eleverne ikke tog alvorligt. Her fortæller Eva om en situation, hvor hun ikke gjorde det godt nok. Hun slutter af med at fortælle, at nu har hun lært, at man skal tage sig sammen og koncentrere sig.

Da grupperne er færdige med deres forberedelser, mødes de igen $i$ klassen, hvor udvalgte børn skal fortælle om deres valg og begrundelser. Asbjørn fortæller om en dag, hoor han lavede mange regnestykker. Aske spørger: "Ja, og hoad siger det om dig, Asbjørn?" Asbjørn svarer, at det siger noget om, at han godt kan lide at skynde sig, være hurtig og nå meget. Aske siger: "Ja, for portfolioen siger jo ikke bare noget om de ting, I har valgt, men også noget om jer." Mange børn er ivrige efter 
at præsentere deres produkter. Aske roser dem for at have lyst til at fortælle. Han siger: "Det er så dejligt, at mange gerne vil have blærerøvstid." (Observation 3. klasse)

Det er værd at bemærke, at børnene til forskel fra det forrige eksempel arbejder sammen om at evaluere deres udbytte af undervisningen, til trods for at portfolio som udgangspunkt er en samling af børnenes individuelle produkter. Netop samværet og den sociale interaktion ser ud til at støtte børnene og give dem inspiration til, hvordan de kan præsentere og begrunde deres valg af produkter. Med inspiration fra Helle Rabøl Hansen kan dette evalueringsarbejde beskrives som understøttet af en fællesskabende didaktik, hvor faglighed og socialitet forstås som indbyrdes forbundet (Hansen, 2014). Herunder indgår fællesskabsopbyggende processer som en integreret del af undervisningen, og netop den sociale interaktion har en støttende og stilladserende funktion for mange af børnene. Gennem samarbejdet med klassekammeraterne får børnene inspiration til sproglige vendinger og refleksioner, der kan være nyttige for at kunne positionere sig som en skoledygtig elev. Det bliver så at sige en frlles sag at løse opgaven. Derudover giver den sociale interaktion mulighed for at eksperimentere med rollen som et evalueringsdygtigt subjekt, der kan præsentere og reflektere over sit udbytte af undervisningen. Til trods for at rollespillet giver indtryk af, at evaluering 'bare er noget, vi leger', rummer rollespillet samtidigt en vis alvor, for alle vil gerne fremstå som dygtige til den forestående skole-hjem-samtale og høste ros for deres indsats.

Derudover er det værd at bemærke, at dygtighed ikke kun handler om børnenes faglige præstationer eller deres evner til at vurdere dette. "Den siger også noget om jer", som læreren så venligt minder børnene om. Netop dette citat illustrerer, at der er ganske meget på spil, når børn skal evaluere sig selv. Det handler ikke kun om, hvordan de klarer sig fagligt, selvom det umiddelbart kan forekomme sådan - også børnenes person bliver (om end implicit) genstand for vurdering. Skoledygtighed bliver dermed også her et komplekst fænomen, som retter sig mod barnets faglige og sociale kompetencer såvel som barnets personlighed på måder, der kan være svære at orientere sig i (Grumløse et al., 2020). Det betyder samtidig, at evalueringen for nogle børn kan blive en relativ sårbar og risikofyldt affære. En ting er at få devalueret sin faglighed, noget andet er at få devalueret sin personlighed. 


\section{Læringsoptimering og social sortering}

Når selvevalueringsteknologier som portfolio har fået en plads i skolen, hænger det som tidligere beskrevet sammen med intentionen om at optimere børnenes udbytte af undervisningen. Her spiller evalueringer en central rolle, fordi evalueringer kan hjælpe os til at blive klogere på, hvad børnene kan eller har svært ved. Det er der for så vidt ikke noget nyt i. Det nye består derimod i kombinationen af ambitionen om, at børns udbytte af undervisningen skal maksimeres, og ideen om, at indsigt i egne læreprocesser understøtter børnenes læring (Kousholt et al., 2019). I den sammenhæng anvendes selvevalueringer ikke blot som et redskab til at øge børnenes læring. De bidrager også med et øget krav om, at barnet skal påtage sig ansvaret for at lære mere og bedre. Det kommer blandt andet til udtryk gennem brugen af portfolio i skolen, hvor børnene skal reflektere over, hvad de har lært, og gennem præsentationer af udvalgte produkter, der eksemplificerer deres styrker og svagheder, forventes at påtage sig ansvaret for at arbejde med faglige, sociale og/eller personlige forhold, der kan styrke det fremtidige udbytte af undervisningen. Men til skole-hjem-samtalerne, hvor børnene præsenterer deres portfolio for lærere og forældre, er der stor forskel på, hvordan børnene forpligtes på at tage ansvar for deres videre læring. Nogle børn sendes hjem med ganske store mængder af hjemmearbejde, der særligt retter sig mod udvikling af faglige kundskaber, mens andre børn udelukkende høster ros for deres indsats og opmuntres til at være lidt mere loose med skolearbejdet (Grumløse et al., 2020). Ikke overraskende er det særligt den gruppe af børn, der har vanskeligt ved at honorere de faglige krav, der sendes hjem med reprimander om at arbejde hårdere. Mens de mere skoledygtige børn går styrkede hjem, fyldt op af rosende ord. Vi betragter dette som et eksempel på, at skolen fortsat bidrager til social sortering (Bourdieu \& Passeron, 2006) trods en skolepolitisk målsætning om at bryde med den sociale arv, og vi vurderer, at sorteringen styrkes, i takt med at evalueringsformerne bliver flere og evalueringslandskabet får flere facetter.

Der er ingen tvivl om, at lærernes handlemuligheder i mange tilfælde er begrænsede, og mange oplever, at den faglige dømmekraft, de lærerfaglige begrundelser og didaktiske kompetencer sættes i parentes, når bestemte måder at afvikle undervisning på er påkrævet. Herunder krav om fx brug af portfolio i undervisningen eller læringsplatforme og de dertilhørende evalueringsaktiviteter, som er 'indbygget' i systemerne. Krav som disse kan være initierede af skolens ledelse eller kommunalt bestemt. Men også landspoli- 
tisk har vi set, at man $\mathrm{fx}$ med den tidligere beslutning om at implementere læringsplatforme i folkeskolen går meget tæt på den enkelte lærers undervisning, og man gør det, fordi man mener, at det er godt for kvaliteten af undervisningen (Kommunernes Landsforening, 2018). Disse lag er væsentlige at have for øje, når man til tider kan undre sig over, hvorfor undervisningsformerne ikke altid er begrundet fagligt af den pågældende lærer og dermed initieret af den faglige dømmekraft. Det pres på lærerfagligheden, som de seneste i hvert fald 25 år har budt på, kan ses som 'frugten' af, at man i sin iver efter at give alle børn den bedste undervisning og uddannelse har været optagede af undervisningens form og indhold snarere end børnenes forskellige forudsætninger og forskellige måder at deltage i undervisningen på. Én forklaring på relativt rigide selvevalueringspraksisser i skolen $\mathrm{i}$ dag kan således være, at lærere mødes med krav om tydelige læringsmål, løbende evalueringer, dokumentation af undervisning og anvendelse af læringsplatforme, krav og forventninger til form og indhold, der i høj grad er ledelses- eller forvaltningsinitieret eller politisk bestemt.

Når lærere tilmed præsenteres for undersøgelser, der dokumenterer, at evaluering bidrager til at styrke børnenes udbytte af undervisningen ( $\mathrm{f} x$ Kommunernes Landsforening, 2018), og selvevaluering derudover menes at styrke børnenes ansvar for egen læring, bliver kravet om evaluering tæt på det enkelte barn vanskeligt at komme udenom. Således kan man betragte selvevalueringsaktiviteter som teknikker, der sniger (Thomsen, 2017) eller glider (Moos (red.) 2019) ubemærket ind i skolens fag og praksis og bliver del af dagligdagens rutiner trods en samtidig bevidsthed om, at aktiviteterne ikke nødvendigvis styrker alle børns faglige selvforståelse og deltagelsesmuligheder i skolen. Ja, faktisk forringes nogle børns oplevelser af skolen betragteligt i disse aktiviteter. Der er i dag ganske mange forhold, man som elev kan fejle i. Man kan være mindre dygtig til fag, end læreren ønsker det. Man kan være dårligere til at vurdere, hvad man kan, end det forventes. Man kan have svært ved at afstemme sine egne vurderinger med lærerens vurderinger. Når vi samtidig ser børn, der efterlades med ansvaret for at forbedre sig - gerne derhjemme med støtte fra forældrene, i det omfang forældrene har muligheder og ressourcer til at støtte børnene i at honorere skolens krav. Når oplevelsen af ikke at kunne slå til i skolen på sin vis bliver en barskere oplevelse, når barnet selv forventes at komme til den erkendelse, handler det om, at det ikke bliver muligt at skyde den fra sig. Barnet forventes selv at erkende, hvad det ikke mestrer. For nogle børn er det let at reparere på, fordi det drejer sig om ganske lidt, eller fordi forældrene kan hjælpe. For 
andre børn drejer det sig om ganske meget, og erkendelserne bliver en del af barnets selvforståelse af at være utilstrækkelig, langsom eller dum (Grumløse et al., 2020).

\section{Lærerfaglighed, evalueringskoncepter og social sortering}

Selvom det er en politisk hensigt, at alle børn skal blive så dygtige, som de kan (Folkeskolereformen, 2014; Kousholt \& Hamre, 2016), er virkeligheden i dag, at langt fra alle børn har glæde af den individfokuserede læringsdagsorden og undervisning, som aktuelt udspiller sig rundt omkring på landets skoler, og som blandt andet kommer til udtryk i en voksende trang til at benytte selvevaluering i undervisningen (fx Wandal, 2018). Børn skal kunne ville, som Kristine Bagge Kousholt formulerer det (Kousholt, 2009; Kousholt et al., 2019). Det betyder i praksis, at børn skal kunne indgå i undervisningen på en ret snæver måde, der både får betydning for, hvordan de kan tage del i undervisningen, og hvordan de kan forstå sig selv. I eksemplet med evalueringer af mål i læringsplatformen evaluerer børnene hver især deres udbytte af undervisning, med den konsekvens, at de børn, der har vanskeligt ved at leve op til de faglige krav, må søge alternative veje til at finde de rigtige svar eller efterlades med følelsen af utilstrækkelighed. De individualiserede evalueringsformer kan dermed siges at reducere børnenes deltagelsesmuligheder og oplevelser af mestring i skolen. Kun nogle kan deltage på måder, der anerkendes af læreren.

Eksemplet med portfolio vidner derimod om, at en fællesskabende didaktisk praksis kan styrke børnenes deltagelsesmuligheder i evalueringsaktiviteterne og deres muligheder for at præsentere sig som skoledygtige individer. Men i begge eksempler kommer aktiviteterne også ganske tæt på børnene som personer og rummer potentielt faren for, at ikke blot barnets faglige kompetencer fremstår som utilstrækkelige, men også barnets personlige kompetencer. Denne kiggen indad kan, som lektor i pædagogik Kari Lyngholm Thomsen formulerer det, ende med at være en utålelig cocktail, der belaster barnets meningsperspektiver, mentale vaner og identitetsdannelse (Thomsen, 2017). Vi betragter Alfreds oplevelser som et eksempel på 'en utålelig cocktail'.

Selvom hensigten fra politisk hold er den modsatte, etableres således en række skel mellem de børn, 'der kommer i klemme', og de børn, som ikke kommer i klemme, og som særligt skole-hjem-samtalerne i forbindelse med portfolioarbejdet vidner om: Man har større risiko for at komme i klemme, 
hvis man ikke har forældre, der nemt og ubesværet indgår i samarbejdet med skolen (Kryger et al., 2012). Denne viden er i og for sig ikke ny. Vi ved, at skolen reproducerer samfundets sociale strukturer også i dansk sammenhæng (Akselvoll, 2016; Bourdieu \& Passeron, 2006; Hedegaard-Sørensen \& Grumløse, 2016; Gilliam, 2012), og den gør det i mange sammenhænge. Hvor vidtrækkende konsekvenserne af den aktuelle sortering er, er dog fortsat noget, vi må interessere os for i såvel forskning som praksis. De empiriske nedslag, vi har valgt at medtage i denne artikel, vidner om, at de tilbagevendende evalueringer ligeledes bidrager til at nedbryde nogle børns forestillinger om sig selv som skoledygtige børn - især de individualiserede evalueringsaktiviteter ser ud til at have betydning for børnene. Der er god grund til at tro, at der kan være en forbindelse mellem det, man inden for ungdomsforskningen betegner som 'den nye udsathed' (Görlich, 2019), og tilbagevendende krav om at kunne vurdere sig selv på mange parametre barndommen og ungdomslivet igennem.

I forlængelse heraf giver det god mening fortsat at stille spørgsmål ved, hvorvidt den uddannelsespolitiske optimeringsdrøm med fokus på tilbagevendende vurderinger af børnenes skolepræstationer er kontraproduktive i forhold til at komme social sortering til livs.

\section{Referencer}

Akselvoll, M.Ø. (2016). Folkeskole, forældre, forskelle: Skole-hjem-samarbejde og forældreinvolvering $i$ et forældreperspektiv. Ph.d.-afhandling. Roskilde Universitet.

Berg, M.S. (2018). Kroppens betydning for lærerens lederskab. Ph.d.-afhandling.

Københavns Universitet.

Andersen, P.Ø (2011). Pædagogikken i evalueringssamfundet. Hans Reitzels Forlag.

Bjørgen, I.A. (2008). Ansvar for egen læring. Tidsskrift for Norsk psykologforening, 45(7), 862866.

Bourdieu, P. \& Passeron, J.C. (2006). Reproduktionen - bidrag til en teori om undervisningssystemet. Hans Reitzels Forlag.

Dahler-Larsen, P. (2005). Evalueringskultur - et tiltrækkende begreb?. Unge Pædagoger, 2/3, 3-8.

Dannesboe, K.I., Kryger, N., Palludan, C., \& Ravn, B. (2012). Hvem sagde samarbejde? Et hverdagslivsstudie af skole-hjem- relationer. Aarhus Universitetsforlag.

Dressler, M. \& Obel, C. (2017). Vredeshåndtering for unge - forstå og håndter følelserne i fællesskab. Frydenlund.

Dysthe, O. (2009). Evaluering i klassen til støtte for læring. KvaN, 85.

Ecclestone, K. (2003). Understanding assessment and qualifications in post-compusory education. NIACE.

Engsig, T.T. (2019). Har den evidensbaserede videnskab taget magten over den professionelle dømmekraft? Dansk Pædagogisk Tidsskrift, (1), 6-15.

Frykman, J. (2005). En lys fremtid? Skole, social mobilitet og kulturel identitet. Unge Pædagoger. 
Gilliam, L. (2012). Sociale børn og gode klasser: Konstruktionen af civiliserede fællesskaber i skolen. I: Civiliserende institutioner: Om idealer og distinktioner i opdragelse (s. 119-157). Antropologiske Studier, Bind. 1. Aarhus Universitetsforlag.

Grumløse, S.P., Kaas, L.A., \& Berg, M.S. (2020). Jeg må være den dummeste i klassen. Samfundslitteratur.

Görlich, A., Pless, M. Katznelson, N., \& Graversen, L. (2019). Ny udsathed i ungdomslivet. 11 forskere om den stigende mistrivsel blandt unge. Hans Reitzels Forlag.

Gulløv, E., \& Højlund, S. (2015). Feltarbejde blandt børn - metodologi og etik i etnografisk børneforskning. Gyldendal.

Hamre, B. (2012). Potentialitet og optimering: problemforståelser og optimering i skolen. Ph.d.-afhandling. Institut for Uddannelse og Pædagogik (DPU), Aarhus Universitet.

Hansen, H.R. (2014). Fællesskabende didaktikker. Pædagogisk Psykologisk Tidsskrift, 31.

Hastrup, K., Rubow, C., \& Tjørnhøj-Thomsen, T. (2017). Kulturanalyse kort fortalt. Samfundslitteratur.

Hedegaard-Sørensen, L. (2015). Praksisfortællinger og lektionsbeskrivelser. KvaN, 103.

Hedegaard-Sørensen, L., \& Grumløse, S.P. (2016). Lærerfaglighed, inklusion og differentiering: Pædagogiske lektionsstudier i praksis. Samfundslitteratur.

Højholt, C., \& Kousholt, D. (red.) (2018). Konflikter om børns skoleliv. Dansk Psykologisk Forlag.

Højholt, C., \& Witt, G. (red.) (1996). Skolelivets socialpsykologi-Nyere socialpsykologiske teorier og perspektiver. Unge Pædagoger.

Illeris, K (2014). Læring i konkurrencestaten. Kapløb eller bæredygtighed. Samfundslitteratur.

Juhl, P. (2014). På sporet af det gode børneliv: Voksnes bekymring og børns perspektiver på problemer $i$ hverdagslivet. Ph.d.-afhandling. Roskilde Universitet.

Knudsen, H. (2015). De blinde pletter i synlig læring: hvordan evidens blev svaret på det hele og glemte de andre spørgsmål, man også kan stille. I: Bjerg, H., \& Vaaben, N. (red.), At lede efter laring (s. 125-148). Samfundslitteratur.

Kommunernes Landsforening (2018). Læringsplatforme har givet elever overblik.

https://www.kl.dk/nyhed/2018/juni/laeringsplatforme-har-givet-elever-overblik/

Kousholt, K. (2009). Evalueret: Deltagelse i folkeskolens evalueringspraksis. Ph.d.-afhandling. Danmarks Pædagogiske Universitetsskole, Aarhus Universitet.

Kousholt, K., \& Hamre, B.F. (2016). Testing and school reform in Danish education: an analysis informed by the use of 'the dispositive'. I: Smith, W.C. (red.), The global testing culture: shaping education policy, perceptions, and practice (s. 231-247). Symposium Books, Oxford Studies in Comparative Education, No. 1, Vol. 25.

Kousholt, K.B., Krejsler, J.B., \& Nissen, M. (red.) (2019). At skulle ville: om motivationsarbejde og motivationens tilblivelse og effekter. Samfundslitteratur.

Krejsler, J.B. (2014). Når nye sociale teknologier sætter kursen. I: Krejsler, J.B., \& Moos, L. (red), Klasseledelsens dilemma. Dafolo

Krejsler, J.B. (2019). 'Den store simulation', evalueringsfeber og motivationseffekter. Baudrillard-refleksioner over drive i dansk og national skolepolitik. I: Kousholt, K.B., Krejsler, J.B., \& Nissen, M. (red.), At skulle ville. Om motivationsarbejde og motivationens tilblivelse og effekter. Samfundslitteratur.

Laursen, P.F. (2017). Evidens: Nonspecifikke kvaliteter fremmer læring. KvaN, 107, 80-90.

Madsen, C. (red.) (2006): Evalueringsfaglighed i skolen. Unge Pædagoger.

Mardahl-Hansen, T. (2019). Teaching as a social practice. Nordic Psychology, 71(1), 3-16.

Moos, L. (red.) (2019). Glidninger 'Usynlige' forandringer inden for pædagogik og uddannelser. DPU, Aarhus Universitet. 
Palludan, C. (2017). Ulighed - institutionaliserede dominanslogikker. I: Gulløv, E., Nielsen, G.B., \& Winther, I. (red.), Pædagogisk antropologi. Tilgange og begreber. Hans Reitzels Forlag.

Pasgaard, N.J. (2017). FAQ om læringsmål. Hans Reitzels Forlag.

Pedersen, O.K. (2011). Konkurrencestaten. Hans Reitzels Forlag.

Pedersen, C. (2017). Om dømmekraften. Akademisk Forlag.

Skaalvik, E.M., \& Skaalvik, S. (2015). Motivation for læring. Dafolo.

Skovmand, K. (2019). Folkeskolen efter læringsmålstyringen? Hans Reitzels Forlag.

Stanek, A.H. (2011). Børns fxllesskaber og fxllesskabernes betydning - analyseret $i$ indskolingen fra børnehave til 1. klasse og SFO. Ph.d.-programmet i Hverdagslivets Socialpsykologi, Institut for Psykologi og Uddannelsesforskning.

Thomsen, K.L. (2017). Elevens læring og udvikling - hvor vil vi hen? KvaN, Tidsskrift for læreruddannelse og skole, 107.

Wandall, J. (2018). Data om elevernes udvikling kan give lærerne ny viden. Skoleliv, november. 